Uvarova N, Kadiyeva M. Analysis of the results of female speed sports climbing on reference track and prospects

of its development in Ukraine. Theory and Methods of Physical education and sports. 2019; 1: 47-51

DOI:10.32652/ tmfvs.2019.1.47-51
Уварова Н, Кадієва М. Аналіз результатів швидкісного спортивного лазіння на еталонній трасі серед жінок і перспективи його розвитку в Україні. Теорія і методика фізичного виховання і спорту.2019;1: 47-51 DOI:10.32652/tmfvs.2019.1.47-51

\title{
АНАЛІЗ РЕЗУЛЬТАТІВ ШВИДКІСНОГО СПОРТИВНОГО ЛАЗІННЯ НА ЕТАЛОННІЙ ТРАСІ СЕРЕД ЖІНОК І ПЕРСПЕКТИВИ ЙОГО РОЗВИТКУ В УКРАЇНІ
}

\section{Настасія Уварова, Маргарита Кадієва}

\author{
${ }^{1}$ Харківський національний педагогічний університет ім. Г. С. Сковороди, Харків, Україна \\ ${ }^{2}$ Національний університет фізичного виховання і спорту України, Київ, Україна
}

\begin{abstract}
Анотація. В Україні тренується велика кількість талановитої перспективної молоді, а щоб вивести їх на міжнародний рівень необхідне покращення матеріально-технічної бази у регіонах. Тренування на скеледромах, що відповідають міжнародним стандартам, допоможе підняти рівень спортивної підготовленості спортсменів та виховати велику сильну команду лідерів міжнародних змагань, що виступають під прапором України. Мета. Дослідження розвитку лазіння на швидкість серед жінок в Україні (на еталонній трасі), а також перспективи його розвитку на світовому рівні та в нашій державі. Методи. Аналіз результатів протоколів змагань чемпіонату України та найважливіших світових змагань за рік (Всесвітні ігри з неолімпійських видів спорту, чемпіонати світу та Європи) за період з 2011 по 2018 р. Результати. У дослідженні було виділено кращий час проходження еталонної траси, час п'ятий та десятий за часовим показником. Також було проаналізовано матеріально-технічну базу України з приводу наявності еталонних скеледромів у різних областях та регіонах. Виявили, що серед українських спортсменів часові проміжки проходження дистанції мають суттєву різницю. Особливо великий відрив між першими двома-трьома результатами та результатами спортсменок другої п'ятірки (6-10-те місця на чемпіонаті України). Це свідчить про наявність сильних лідерів та набагато слабкішого порівняно з ними другого ешелону спортсменів, тоді як на міжнародних змаганнях усі результати першої двадиятки спортсменів розташовані дуже щільно. Учасниці змагань з відставанням у 2-3 с знаходяться за межами тридиятих місць. Що стосується матеріально-технічної бази для тренування швидкісного лазіння на еталонній трасі, на сьогодні в Україні існує тільки один скеледром у приміщенні з висотою еталонної стінки 15,5 м в Одесі, що істотно ускладнює тренувальний процес спортсменів в базовий підготовчий період, який відбувається в зимовий час.
\end{abstract}

Ключові слова: скелелазіння, багатоборство, швидкість, еталон.

\section{Nastasiia Uvarova, Marharyta Kadiyeva \\ ANALYSIS OF THE RESULTS OF FEMALE SPEED SPORTS CLIMBING ON REFERENCE TRACK AND PROSPECTS OF ITS DEVELOPMENT IN UKRAINE}

\begin{abstract}
A large number of talented, promising young people are training in Ukraine, Bringing them to the international level necessitates the improvement of the material and technical base in the regions. Training on climbing walls that meets international standards will help raise the level of athletic fitness and nurture a strong team of international competition leaders that compete under the banner of Ukraine. Objective. To study the development of women speed climbing in Ukraine (on the reference track), as well as prospects for its development at the world level and in our country. Methods. Analysis of the results of competition protocols of Ukrainian Championship and the most important world competitions during the year (World Games in the non-Olympic sports events, World and European Championships) for the period from 2011 to 2018. Results. The study highlighted the best time to pass the reference track, the fifth and tenth time by time. Besides, the material and technical basis of Ukraine concerning the availability of reference climbing walls in different districts and regions was analyzed, and it was found that among Ukrainian athletes, time intervals for passing the distance have a significant difference. Especially large gap exists between the first two or three results and results of athletes of the second five (6-10 places in the championship of Ukraine). This indicates the availability of strong leaders and much weaker the second echelon of athletes, while at the international competitions all the results of the first twenty athletes are very tight. Participants of the competition with a gap of 2-3 s are located outside the thirtieth places. With regard to the material and technical base for training of speed climbing on the reference track, today in Ukraine there is only one climbing wall in the room with a height of the reference wall of $15.5 \mathrm{~m}$ in Odessa, which greatly complicates the training process of athletes during the basic preparatory period that takes place in winter time.
\end{abstract}

Keywords: climbing, all-round, speed, reference.

Вступ. Беручи до уваги, що уже у 2020 р. Токіо прийматиме Олімпійські ігри, на яких вперше буде представлено скелелазіння, питання порівняння можливостей українських скелелазів з резуль- татами світових лідерів є актуальним. До програми Олімпійських ігор включено дисципліну багатоборство, підведення підсумків у якому проводиться за результатами виступу спортсмена у змаганнях 


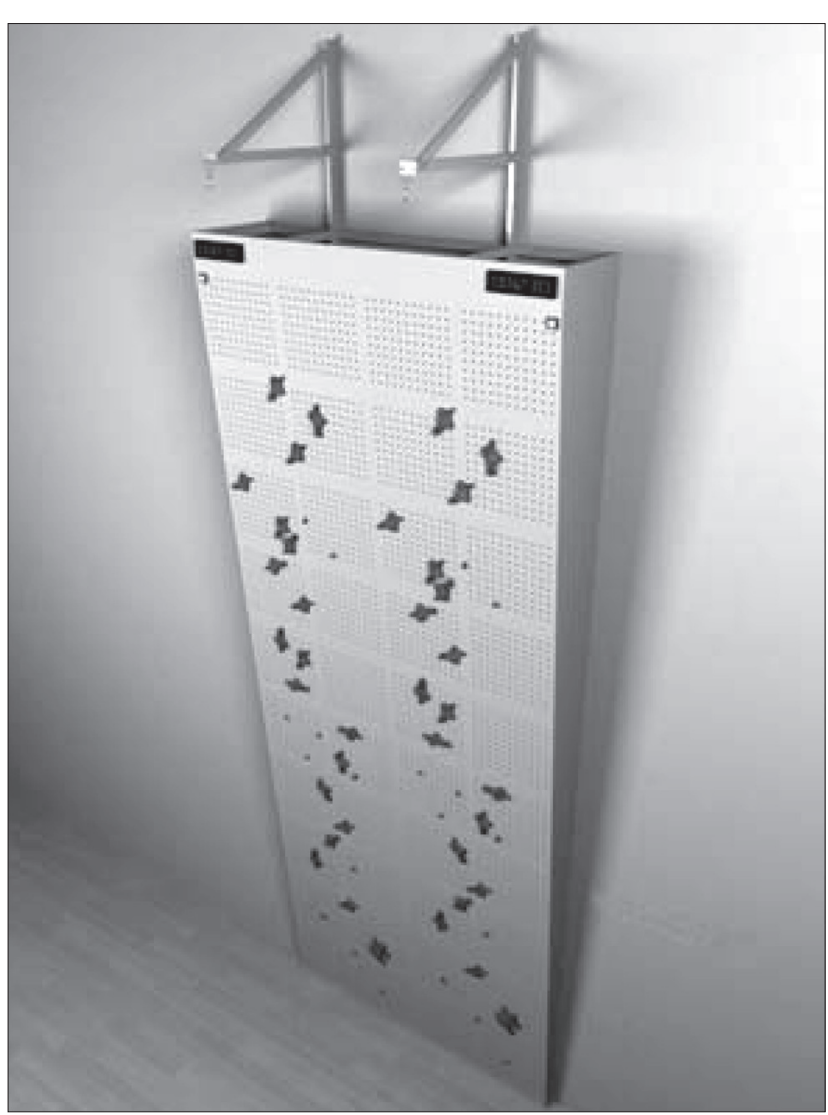

Рисунок 1 - Еталонна траса для лазіння на швидкість у фрорматі «рекорд»

3 лазіння на швидкість (швидкісний підйом на трасу висотою 15 м), лазіння на складність (враховується висота підйому за обмежений проміжок часу) та боулдерингу (подолання коротких надскладних трас, залік проводиться за кількістю зафіксованих основних та проміжних фінішів) [16].

Опробування еталонної траси відбулося на зимових Олімпійських іграх у Турині. Перший старт на чемпіонаті світу відбувся в Іспанії у 2007 р. 3 того часу всі офіційні змагання у лазінні на швидкість проводяться тільки на ній. Змагання на швидкість у форматі «рекорд» проводяться на еталонній трасі довжиною 15 м (рис. 1). Саме на ній спортсмени встановлюють рекорди світу. Траса повинна відповідати вимогам Міжнародної федерації спортивного скелелазіння (IFSC), на змаганнях необхідно використовувати сертифіковане обладнання (стартові платформи, фінішні кнопки, автоматична страховка тощо), яке має відповідати стандартам швидкісного лазіння [17].

Чемпіонати України на еталонній трасі почали проводити, починаючи 32011 р., а з багатоборства - в 2017 р. Молодий спортсмен Ярослав Ткач 3 Кропивницького виборов право представляти нашу країну на III Юнацьких Олімпійських іграх, що пройшли у жовтні 2018 р. у Буенос-Айресі (Аргентина). Українські спортсмени планують вибороти ліцензії на Ігри Олімпіад у Токіо 2020, а завдання тренерів та науковців допомогти їм у цьо- му, аналізуючи перспективи розвитку скелелазіння як олімпійського виду спорту [2]. Вивченням особливостей тренувального процесу спортсменів, які спеціалізуються у лазінні на швидкість, займалися О. О. Репко, Ж. Л. Козіна, О. С. Шульга $[4,5,8,11]$. Питанням фізіології у скелелазінні займалися A. W. Sheel, A. В. Morrison \&\& V. R. Schöffl [9, 13], дослідженням розвитку рівноваги у спортсменів-скелелазів та її впливу на спортивний результат присвячені статті P. B. Watts, K. P. Drobish [15], M. Ignjatović, D. Stanković, S. Pantelić Puletić [6], Schweizer, Andreas \& Furrer [12] та безпосередньо автора статті [3]. Психологію скелелазів різної спортивної кваліфікації дослідженно у статтях Nick Draper \& Jones Glenys \& Fryer Simon \& Hodgson Christoher \& Blackwell Jones, G. A., Fryer, S., Hodgson, C., \& Blackwell, G. $[1,7,10,14]$.

Мета дослідження - аналіз розвитку швидкісного лазіння серед жінок в Україні, перспективи його розвитку на світовому рівні та в нашій державі.

Методи дослідження: аналіз протоколів змагань чемпіонату України та найважливіших світових змагань за рік (Всесвітні ігри з неолімпійських видів спорту, чемпіонати світу та Свропи) за період з 2011 по 2018 р.

Результати дослідження та їх обговорення. У ході дослідження було виділено кращий час на проходження еталонної траси, час п'ятий та десятий за часовим показником. Також було проаналізовано матеріально-технічну базу України 3 приводу наявності еталонних скеледромів у різних областях та регіонах.

Автором було висунуто припущення, що чим більше сильних спортсменів бере участь у змаганнях, тим менші часові відстані між їхніми результатами. I порівняння саме цих часових проміжків серед лідерів українських скелелазок та світових лідерів може об'єктивно показати рівень розвитку швидкісного лазіння в Україні.

Об'єктом дослідження були спортсменки-скелелазки, які виступають на чемпіонатах України і результат яких входить до 10 кращих, та спортсменки, котрі показують кращі 10 результатів на міжнародних змаганнях (було взято найважливіший міжнародний старт року - чемпіонат світу, Свропи, Всесвітні Ігри 3 неолімпійських видів спорту).

Предметом дослідження був час проходження еталонної траси на найвідповідальніших стартах року. Було виділено найкращий час проходження траси на змаганнях, п'ятий та десятий час проходження траси серед першої десятки лідерів змагань.

Завданням дослідження передбачалося виділення часового проміжку, що відрізняє час однієї спортсменки, та порівняння цих часових проміжків між учасницями українських та світових змагань. Результати проходження еталонної траси на швидкість на чемпіонатах України (ЧУ) та світових змаганнях (С3) з 2011 по 2018 рр. представлено у таблиці 1. Ми маємо можливість порівняти кращий час на змаганнях, п'ятий та десятий результати. 
Було виявлено, що у 2011 р. розрив між 1-м та 10-м результатами на чемпіонаті України становив 4,53 с, а середня відстань між спортсменками $-0,5$ с. На чемпіонаті світу того самого року відстань між спортсменками у першій десятці становила 1,45 c, а середній часовий інтервал між їхнім часом проходження траси - 0,16 с (табл. 2).

Досить цікавим є той факт, що у 2011 р. відстань між 1-м та 5-м результатом становила 0,20 c, середній часовий інтервал між спортсменками 0,05 с. Відповідні показники між 5-м та 10-м місцем: 1,25 с, та 0,25 с середній інтервал.

У 2017 р. на Всесвітніх іграх відповідні показники відстані між 1-м та 10 -м результатом становили 1,53 с, а середній часовий інтервал проходження траси - 0,17 с. На чемпіонаті України різниця між 1-м та 10-м результатом становила 3,33 , часовий інтервал - 0,37. Відстань між першим та п'ятим часом на чемпіонаті України у 2018 р. 3,02 c, на чемпіонаті світу - 0,236 с.

Зауважимо, що значно скорочується відрив між 5-м та 10-м місцем на світових змаганнях, що свідчить про підвищення загального рівня жінок, які спеціалізуються у швидкісному лазінні. На передній план виходять психологічні здатності спортсмена зберігати спокій та контроль над ситуацією і його здатність до ризику одночасно [11].

У вітчизняному скелелазінні поки що рівномірно скорочується середній часовий інтервал між часом проходження траси 3 0,5 до 0,37 c, але до світової тенденції часового інтервалу від 0,02 до 0,17 с ще далеко (табл. 3). До речі, на світових змаганнях часові проміжки різниці приблизно однакові між всіма спортсменками, а в Україні найбільший відрив слід відзначити між спортсменкам першої п'ятірки (понад 3 с), що свідчить про наявність сильних лідерів та набагато слабшого другого ешелону спортсменів, тоді як на світових змаганнях усі результати розташовані дуже щільно, а учасниці, які відстають від лідерів на 2-3 с залишаються за межами кращих 30 спортсменів. Це свідчить про необхідність загального підвищення рівня швидкісного лазіння в нашій країні.

Для повноцінних тренувань в усіх видах спорту важливу роль відіграє наявність матеріальнотехнічної бази. На сьогодні в Україні існують повноцінні еталонні траси висотою 15 м та шириною 6 м в Одесі (скеледром на вул. Фонтанній, 4a), Дніпрі, Нікополі, Харкові, Кривому Розі. 3 них тільки одна знаходиться у приміщенні (м. Одеса) та придатна для тренування спортсменів у осінньо-зимово-весняний період.

Скеледроми висотою 15 м та шириною менше 6 м знаходяться у Кременчуку та Одесі (скеледром альпклубу «Одеса»), коротші стінки у приміщенні (висотою 10 м) - у Кременчуку, Харкові та Нетишині. Існує скеледром на вулиці у Кропивницькому, прикріплений мотузками до дерев. Тренуючись саме на ньому, Сергій Побережець виграв чемпіонат світу серед молоді в 2008 р. (рис. 2).
Таблиця 1 - Результати проходження еталонної траси жінками на міжнародних змаганнях та чемпіонатах України

\begin{tabular}{|c|c|c|c|c|c|c|}
\hline \multicolumn{3}{|c|}{ Кращий час, с } & \multicolumn{4}{c|}{ Результат, с } \\
\hline Рік & чу & C3 & чу 5-й & (3, 5-й & чУ, 10-й & (3, 10-й \\
\hline 2018 & 8,47 & 7,56 & 11,49 & 7,795 & 12,28 & 8,037 \\
\hline 2017 & 8,55 & 7,32 & 10,51 & 8,04 & 11,88 & 8,85 \\
\hline 2016 & 8,55 & 7,52 & 10,13 & 8,12 & 13,36 & 8,41 \\
\hline 2015 & 8,37 & 7,78 & 10,1 & 8,1 & 13,08 & 8,62 \\
\hline 2014 & 9,66 & 8,38 & 11,02 & 8,25 & 13,35 & 8,52 \\
\hline 2013 & 9,91 & 8,12 & 11,62 & 8,65 & 14,07 & 9,47 \\
\hline 2012 & 9,78 & 8,37 & 11,72 & 8,9 & 12,06 & 9,8 \\
\hline 2011 & 11,15 & 9,57 & 12,71 & 9,77 & 15,68 & 11,02 \\
\hline
\end{tabular}

Таблиця 2 - Різниця в часі проходження еталонної траси жінками на чемпіонатах України та світових змаганнях, с

\begin{tabular}{|c|c|c|c|c|c|c|}
\hline \multirow{2}{*}{ Рік } & \multicolumn{7}{|c|}{ Результат, с } \\
\cline { 2 - 7 } & $\begin{array}{c}\text { 4у 1-й } \\
\text { та 5-й }\end{array}$ & $\begin{array}{c}\text { C3 1-й } \\
\text { та 5-й }\end{array}$ & $\begin{array}{c}\text { 4у 5-й } \\
\text { та 10-й }\end{array}$ & $\begin{array}{c}\text { C3 5-й } \\
\text { та 10-й }\end{array}$ & $\begin{array}{c}\text { 4y 1-й } \\
\text { тa 10-й }\end{array}$ & $\begin{array}{c}\text { C3 1-й } \\
\text { та 10-й }\end{array}$ \\
\hline 2018 & 3,02 & 0,236 & 0,79 & 0,241 & 3,81 & 0,477 \\
\hline 2017 & 1,96 & 0,72 & 1,37 & 0,81 & 3,33 & 1,53 \\
\hline 2016 & 1,58 & 0,60 & 3,23 & 0,29 & 4,81 & 0,89 \\
\hline 2015 & 1,73 & 0,32 & 2,98 & 0,52 & 4,71 & 0,84 \\
\hline 2014 & 1,36 & 0,13 & 2,33 & 0,27 & 3,69 & 0,14 \\
\hline 2013 & 1,71 & 0,53 & 2,45 & 0,82 & 4,16 & 1,35 \\
\hline 2012 & 1,94 & 0,53 & 0,34 & 0,90 & 2,28 & 1,43 \\
\hline 2011 & 1,56 & 0,20 & 2,97 & 1,25 & 4,53 & 1,45 \\
\hline
\end{tabular}

Таблиця 3 - Середній відрив у часі між результатами скелелазок на чемпіонатах України та світових змаганнях

\begin{tabular}{|c|c|c|c|c|c|c|}
\hline \multirow{2}{*}{ Рік } & \multicolumn{7}{|c|}{ Результат, с } \\
\cline { 2 - 7 } & $\begin{array}{c}\text { чу 1-й } \\
\text { та 5-й }\end{array}$ & $\begin{array}{c}\text { C3 1-й } \\
\text { та 5-й }\end{array}$ & $\begin{array}{c}\text { 4у 5-й } \\
\text { та 10-й }\end{array}$ & $\begin{array}{c}\text { C3 5-й } \\
\text { та 10-й }\end{array}$ & $\begin{array}{c}\text { 4У 1-й } \\
\text { тa 10-й }\end{array}$ & $\begin{array}{c}\text { 4C 1-й } \\
\text { тa 10-й }\end{array}$ \\
\hline 2018 & 0,775 & 0,058 & 0,158 & 0,048 & 0,42 & 0,053 \\
\hline 2017 & 0,49 & 0,18 & 0,27 & 0,16 & 0,37 & 0,17 \\
\hline 2016 & 0,40 & 0,15 & 0,65 & 0,06 & 0,53 & 0,1 \\
\hline 2015 & 0,43 & 0,08 & 0,60 & 0,10 & 0,52 & 0,09 \\
\hline 2014 & 0,34 & 0,03 & 0,47 & 0,05 & 0,41 & 0,02 \\
\hline 2013 & 0,43 & 0,13 & 0,49 & 0,16 & 0,46 & 0,15 \\
\hline 2012 & 0,49 & 0,13 & 0,07 & 0,18 & 0,25 & 0,16 \\
\hline 2011 & 0,39 & 0,05 & 0,59 & 0,25 & 0,50 & 0,16 \\
\hline
\end{tabular}

Обмежена матеріально-технічна база значно ускладнює тренувальний процес спортсменів, для відпрацювання лазіння на повній еталонній трасі напередодні змагального сезону (який починається у квітні Кубком світу серед дорослих та Кубком Свропи серед молоді) доводиться виїжджати на навчальнотренувальні збори до Одеси або за кордон.

За період зборів, які тривають два тижні, неможливо повноцінно відпрацювати всі елементи, необхідні для поліпшення рівня спортивної майстерності. За останні десять років Україна втратила позиції лідера у швидкісному лазінні (з появою еталонної траси), і на сьогодні в цьому виді скелелазіння на світових чемпіонатах та першостях регу- 


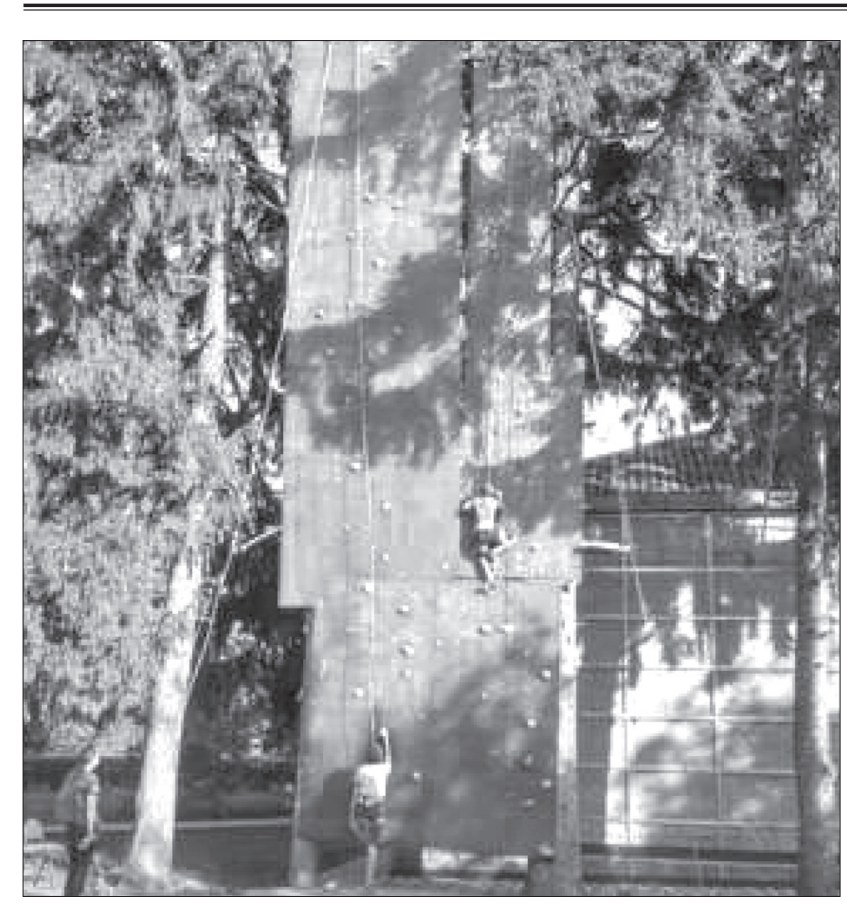

Рисунок 2 - Скеледром у Кропивницькому

лярно виборюють медалі спортсмени Франції, Італії, Росії, Ірану, США, Польщі - країн, які побудували велику кількість еталонних скеледромів та мають змогу для участі у міжнародних змаганнях вибрати дійсно кращих спортсменів своєї країни.

Первинний аналіз наявної матеріально-технічної бази у Харкові показав, що у легкоатлетичному манежі Національного аерокосмічного універ- ситету ім. М. С. Жуковського “ХАI” висота стелі 15,66 м, тобто приміщення придатне для еталонної траси для швидкісного лазіння, тим більше, що там уже існує скеледром для складності.

Найближчим часом планується провести аналіз результатів лазіння на швидкість у чоловіків, а також приділити увагу пошуку взаємозв'язку між результатами окремих дисциплін скелелазіння (швидкості, складності та боулдерингу) у багатоборстві. Дослідження можуть значно полегшити прогнозування спортивних результатів у олімпійській дисципліні скелелазіння - комбінованому заліку.

Висновки. За результатами дослідження виявлено, що в Україні є спортсменки - лідери у лазінні на швидкість (А. Мареніч, Т. Колкотіна), які входять до першого ешелону збірної команди України, та молоді перспективні скелелазки, над спортивною досконалістю яких потрібно багато працювати. Для того щоб збірна команда України стабільно виступала на міжнародних змаганнях, потрібно значно розширити кількість спортсменів, серед яких проводиться відбір, які можуть демонструвати конкурентоспроможні результати (у лазінні на швидкість - час проходження траси). Для цього необхідно проводити роботу на місцях, у регіонах, у окремо взятих ДЮСШ. Якщо допомогти їм обладнати спортивні зали скеледромами, що відповідають олімпійським стандартам, то в дуже короткий час ми побачимо значне поліпшення результатів збірної команди України.

Конфлікт інтересів. Автори заявляють, що відсутній будь-який конфлікт інтересів.

\section{Література}

1. Вивчення психологічних особливостей спортсменів-скелелазів та виявлення зв'язку між ступенем спортивних досягнень та готовністю до ризику. Научное издание «Здоровье, спорт, реабилитация». Журнал по материалам IX Международной конференции «Здоровьесберегающие технологии, реакриация и реабилитация в высших учебных заведениях». Харьков, 2016. 4: 83-86; https://orcid.org/0000-0002-7495-0717 http://sportsscience.org/index.php/health/ article/view/481

2. Сучасні олімпійські перспективи розвитку спортивного скелелазіння. Педагогіка здоров'я: збірник наукових праць VII Всеукраїнської науково-практичної конференції (м. Чернігів, 7-8 квіт. 2017 р.). Том 2: 273-277.

3. Уварова НВ. Проявлення рівноваги у спортсменів-скелелазів високої кваліфікації. Молодь та олімпійський рух: збірник тез доповідей Х Міжнародної конференції, 24-25 травня 2017 року [Електронний ресурс]. Київ, 2017: 183185.

4. Шульга О. С. Фізична підготовленість спортсменів 14-15 років, які спеціалізуються у швидкісному лазінні. Актуальні проблеми фрізичної культури і спорту. 2010; 18 (2): 30-35.

5. Шульга О. С. Модельные характеристики спортсменов-скалолазов специализирующихся в лазании на скорость (формат «рекорд»). Спортивна наука України. 2014; 1 (59): 14-18.

6. Ignjatović M, Stanković D, Pantelić S, Puletić M. The influence of certain anthropometric parameters on the result in lead climbing. Series: Physical Education and Sport Vol. 15. 2. 2017: 321-328 https://doi.org/10.22190/FUPES1702321I

7. Draper N, Jones GA, Fryer S, Hodgson C, \& Blackwell G. (2008). Effect of an on-sight lead on the physiological and psychological responses to rock climbing. Journal of sports science \& medicine.7(4): 492-498.

8. Kozina Z, Ryepko O, Prusik K, Prusik K, \& Cieślicka M. (2014). Theoretical-methodological study of development of power-speed in climbing. Physical Education of Students. 18(1): 27-33. https://doi.org/10.6084/m9.figshare.903690

9. Morrison AB, Schöffl VR. Physiological responses to rock climbing in young climbers. British Journal of Sports Medicine 2007; 41: 852-861. http://dx.doi.org/10.1136/bjsm.2007.034827

10. Nick, Draper \& Jones, Glenys \& Fryer, Simon \& Hodgson, Christoher \& Blackwell, Gavin. (2010). Physiological and psychological responses to lead and top rope climbing for intermediate rock climbers. European Journal of Sport Science. 10: 13-20. https://doi.org/10.1080/17461390903108125 
11. Ryepko OA. Features and functionality of speed and power capabilities of elite climbers and various types of rock climbing.Physical education of student. 2013. 5: 60-65. http://doi.org/10.15561/m9.figshare.840505

12. Schweizer, Andreas \& Furrer M. (2007). Correlation of forearm strength and sport climbing performance. Isokinetics and Exercise Science. 15: 211-216. https://doi.org/10.3233/IES-2007-0275.

13. Sheel AW. Physiology of sport rock climbing. British Journal of Sports Medicine 2004; 38: 355-359. https://dx.doi. org/10.1136/bjsm.2003.008169.

14. Uvarova NV. Studyng the psychological characteristics of mountain athlets and identifying the link between the degree of sporting achievements and readiness to take risks. Матеріали III Науково-практичної інтернет-конференції. «Актуальні питання теорії та практики психолого-педагогічної підготовки фрахівців в умовах сучасного освітнього простору». 175-180.

15. Watts PB, Drobish KP. (1998). Physiological responses to simulated rock climbing at different angles. Medicine and Science in Sports and Exercise. 330: 1118-1122.

16. https://tokyo2020.org/en/games/sport/olympic/sport-climbing/

17. http://www.ifsc-climbing.org/index.php/news/item/322-speed-project-are-you-ready-set-go

\section{Literature:}

1. Study of psychological features of climbers and revealing the link between sports achievement level and readiness to risk. Zdorovye, sport, reabilitatsiya. Kharkov, 2016. 4: 83-86; https://orcid.org/0000-0002-7495-0717 http://sportsscience. org/index.php/health/article/view/481

2. Modern Olympic prospects of sports climbing development. Zbirnyk naukovykh prats VII Vseukrainskoi naukovopraktychnoi konferentsii (Chernihiv, 7-8 Apr. 2017 p.). Vol. 2: 273-277.

3. Uvarova NV. Balance manifestation if highly skilled climbers: zbirnyk tez dopovodei X Mizhnarodnoi konferentsii, 24 25 May 2017. [Electronic resource]. Kyiv, 2017: 183-185.

4. Shulha O. S. Physical fitness of athletes aged 14-15 years specialized in speed climbing. Aktualni problem fizkultury i sportu. 2010. 18 (2): 30-35.

5. Shulha O. S. Model characteristics of speed climbers. Sportyvna nauka Ukrainy. 2014; 1 (59): 14-18.

6. Ignjatović M, Stanković D, Pantelić S, Puletić M. The influence of certain anthropometric parameters on the result in lead climbing. Series: Physical Education and Sport Vol. 15. 2. 2017: 321-328 https://doi.org/10.22190/FUPES1702321।

7. Draper N, Jones GA, Fryer S, Hodgson C, \& Blackwell G. (2008). Effect of an on-sight lead on the physiological and psychological responses to rock climbing. Journal of sports science \& medicine.7(4): 492-498.

8. Kozina Z, Ryepko O, Prusik K, Prusik K, \& Cieślicka M. (2014). Theoretical-methodological study of development of power-speed in climbing. Physical Education of Students. 18(1): 27-33. https://doi.org/10.6084/m9.figshare.903690

9. Morrison AB, Schöffl VR. Physiological responses to rock climbing in young climbers. British Journal of Sports Medicine 2007; 41: 852-861. http://dx.doi.org/10.1136/bjsm.2007.034827

10. Nick, Draper \& Jones, Glenys \& Fryer, Simon \& Hodgson, Christoher \& Blackwell, Gavin. (2010). Physiological and psychological responses to lead and top rope climbing for intermediate rock climbers. European Journal of Sport Science. 10: 13-20. https://doi.org/10.1080/17461390903108125

11. Ryepko OA. Features and functionality of speed and power capabilities of elite climbers and various types of rock climbing. Physical education of student. 2013. 5: 60-65. http://doi.org/10.15561/m9.figshare.840505

12. Schweizer, Andreas \& Furrer M. (2007). Correlation of forearm strength and sport climbing performance. Isokinetics and Exercise Science. 15: 211-216. https://doi.org/10.3233/IES-2007-0275.

13. Sheel AW. Physiology of sport rock climbing. British Journal of Sports Medicine 2004; 38: 355-359. https://dx.doi. org/10.1136/bjsm.2003.008169.

14. Uvarova NV. Studyng the psychological characteristics of mountain athlets and identifying the link between the degree of sporting achievements and readiness to take risks. Матеріали III Науково-практичної інтернет-конференції. «Актуальні питання теорії та практики психолого-педагогічної підготовки фрахівців в умовах сучасного освітнього простору». 175-180.

15. Watts PB, Drobish KP. (1998). Physiological responses to simulated rock climbing at different angles. Medicine and Science in Sports and Exercise. 330: 1118-1122.

16. https://tokyo2020.org/en/games/sport/olympic/sport-climbing/

17. http://www.ifsc-climbing.org/index.php/news/item/322-speed-project-are-you-ready-set-go

Надійшла 16.10.2018

\section{Інформація про авторів}

Уварова Настасія Володимирівна, https://orcid.org/0000-0002-7495-0717 nastasjya.u@gmai.com:
Харьківський національний педагогічий університет ім. Г. С. Сковороди, 61002, м. Харьків, вул. Маршала Бажанова 3.

Кадієва Маргарита Василівна, https://orcid.org/0000-0002-4837-1957 margokad@gmail.com

Національний університет фізичного виховання і спорту України 03150, Київ, вул. Фізкультури, 1

\section{Information about the authors \\ Uvarova Nastasya \\ https://orcid.org/0000-0002-7495-0717 nastasjya.u@gmail.com}

H.S. Skovoroda Kharkiv National Pedagogical University 61002, Kharkiv, Marshal Bazhanov str., 3

Kadiyeva Margaryta https://orcid.org/0000-0002-4837-1957 margokad@gmail.com

National University of Ukraine on Physical Education and Sport, 03150, Kyiv, Fizkul'tury str., 1 